but long may we wait, it is to be hoped, before this event shall happen.

Of the curious nesting habits of Scopus we have excellent accounts from Brehm, Heuglin, and other naturalists who have visited the Upper Nile. But one of our own countrymen, a not less active or experienced observer-bas likewise written a most interesting account of this bird's economy, and we cannot do better than transcribe a part of it.

"The Hammerkop (literally hammerhead)," says Mr. Layard in "The Birds of South Africa," "is found throughout the Colony and all the way to the Zambezi, frequenting ponds, marshes, rivers, and lakes. It is a strange, weird bird, flitting about with great activity in the dusk of the evening, and preying upon frogs, small fishes, \&c. At times, when two or three are feeding in the same small pool, they will execute a singular dance, skipping round one another, opening and closing their wings, and performing strange antics.

"They breed on trees and on rocky ledges, forming a huge structure of sticks, some of them of considerable thickness. These nests are so solid that they will bear the weight of a large, heavy man on the domed roof without collapsing. The entrance is a small hole, generally placed in the most inaccessible side. The eggs, three to five in number, are of a pure white, axis $I^{\prime \prime} 9^{\prime \prime \prime}$; diam. $I^{\prime \prime} 4^{\prime \prime \prime}$.

"On my late friend Jackson's farm, at Nel's Poort, there is a singular rocky glen between two hiils. In this spot a beautiful permanent spring called 'Jackalsfontein' takes its rise. Of course, in consequence, there are a few wild almond and other trees, and the place is a little oasis amid the barren mountains. It is a favourite resort of wild animals, hyænas, leopards, jackals, \&c., and here Mr. Jackson has constructed one of his most successful hyæna-traps. On the ledges of the rocks in this secluded spot a colony of Hammerkops have built for years. Some of the nests are quite inaccessible, while others can be reached with a little trouble. I counted six or eight within fifty yards, and some of them contained at least a large cartload of sticks. Mr. Jackson told me they occupied the same nest year after year, and added to it or repaired it as required. About some that I visited I found brass and bone buttons, bits of crockery, bleached bones, \&c. Mr. Jackson said if a 'Tottie' lost his knife or tinder-box on the farm, or within some miles of the place, he made a point of examining the hammerkops' nests, and frequently with success, the birds, like the 'Bowerbird' of Australia, embellishing their dwellings with any glittering or bright-coloured thing they can pick up."

\section{A SUCCESSFUL AFRICAN EXPEDITION}

$A$ FRICA is overrun with explorers of all nationalities. A Too often of late have we had to read of failures, of abortive attempts on the part of expensively-equipped expeditions to reach the field of their work, or of deaths by fever or assassination after the first difficulties were overcome. In spite of all, however, the unprecedented activity of recent years in this favourite field of exploration has pretty well filled up, with the leading features at least, that great blank space in the heart of the continent which in the rude maps of our schoolboy days was marked "unexplored." In the very centre of that space there is still however a blank, giving ample scope for work for the numerous Belgian expeditions that have hitherto done so little. It was to fill up this blank to some extent that the Geographical Society, about two years ago, obtained subscriptions to send out an expedition under young Keith Johnston, who had inherited an enthusiasm for geographical work quite worthy of the name he bore. As his subordinate and as geologist to the expedition, the Society appointed another young
Scotchman, Mr. Joseph Thomson, a pupil of Prof. Geikie, who recommended him to the Geographical Society. To him, we grieve to say, it has been left to tell the story of the expedition, which he did, and did well, on Monday night at the opening meeting of the Geographical Society. This expedition is remarkable in many respects, in some points more remarkable than any other African expedition that we know of. The outline of its story is soon told. With I 50 of the best men that could be found in and around Zanzibar Keith Johnston left that place in May, 1879, and striking at once to the south-west, made for the north end of Lake Nyassa, which was the real starting-point for fresh work. Little more than a month after the start, young Johnston, who seemed to have the nerve and stamina of an athlete, succumbed to the malarious influences of the coast region, and was buried by his companion at Behobeho, to the north of the Lufiji river. $\mathrm{Mr}$. Thomson, inexperienced youth of twenty-two though he was, was equal to the emergency. With admirable tact and nerve he took his place as the sole leader of the expedition, and accomplished even more than the work which the Society had chalked out for it. By an unexplored route, through barren wistes and over lofty mountains, through the sneaking Wakhutu and the warlike Malenge, he and his followers made their way till their eyes were gladdened and their weary spirits refreshed by the sight of the waters of Nyassa. Thence, after brief rest, they resumed their march over the lofty and undulating plateau, which they found occupied the region between the north end of Nyassa and the south shore of Tanganyika. Leaving here the bulk of his followers, Mr. Thomson, with a handful of men, trudged his way over the rugged western shores of Lake Tanganyika, to visit the Lukuga and settle the question whether it was an outlet or an affluent of the lake, a question, which, one would think, could be easily solved, but on which Stanley and Cameron published diarnetrically opposite statements. After visiting the missionary station near the mouth of the river, and running across to $\mathrm{Ujiji}, \mathrm{Mr}$. Thomson returned to the Lukuga and traced it for some miles of its downward course. After barely escaping from the murderous Warua with their lives, the party sailed down the lake, and rejoining their companions made the return journey to Zanzibar along the usual caravan route with unprecedented rapidity, in about a year after the expedition set out under their late chief. Mr. Thomson declared with just pride that all this was accomplished without the shedding of a drop of blood for either offensive or defensive purposes; with one exception he brought all his men back" in the best of health and condition"; he has collected certain information about a considerable region which no white man had previously visited; he has solved one of the few remaining great problems of African geography; and he has located with certainty a great salt lake (Hikwa) whose existence previously had only been based on native rumour. Mr. Thomson is a trained geologist, and as such he has doubtless seen more than almost any previous explorer. $\mathrm{He}$ tells us of the metamorphic schists and gneiss which compose the mountains of the great central plateau; of the many extinct volcanic cones that lie around the north-west end of Lake Nyassa, and of the metamorphic clay slates, felspathic rocks and volcanic porphyries and tuffs that look down on the lake from the north and north-east. His further geological insight may dispel some of the illusions that seem to be abroad as to the abounding wealth of the African interior. Much of the country between the coast and Nyassa is barren waste; and the chief characteristic of the region betireen Nyassa and Tanganyika he found to be "utter barrenness and the absence of anything worth trading for." Instead of the mountains of iron and the miles of surface coal, nowhere did he see a single metal in a form which a white man would for a moment look at as a profitable or workable speculation; there is very little more iron, he 
maintains, than is sufficient to supply the simple wants of the natives. Coal he saw none, and he does not believe that such a thing exists over the wide area embraced in his route. This may be discouraging, but it is wholesome, and may prove a check to the wild schemes sometimes broached by speculators for opening up the African interior. From the Chimboya Mountains to the southeast of Tanganyika Mr. Thomson found numerous streamlets flowing southwards, doubtless to join the Chambeze, which, after passing through many a lake and levying tribute from a region one million square miles in extent, pours its almost Amazonian volume, as the Congo, 3000 miles below, into the bosom of the broad Atlantic. The much-debated Lukuga he found, as Mr. Hore had found shortly before him, to be a broad and rapid river, flowing westwards from the Tanganyika Lake to the Lualaba, as the Congo here is called; and Lake Hikwa he saw was a fine sheet of water with no outlet, lying among the lofty mountains, which stretch away east from Southern Tanganyika. What may be the extent and value of the purely geographical observations obtained by Mr. Thomson we have no means of knowing; doubtless in this respect the expedition suffered in the death of Mr. Johnston, who was a trained geographer. But in other respects, in information as to the structure of the country, the nature of its products, and the character of its varied peoples, the expedition under $\mathrm{Mr}$. Thomson has been fruitful to a high degree; altogether it is one of the best pieces of original work which our not too energetic Geographical Society has ever done. Mr. Thomson's well-written and wellread paper was received with enthusiasm by an unusually distinguished audience. We trust to be able very shortly to give details concerning both the geography and geology of the Central Plateau from Mr. Thomson's own hands.

\section{UNITED STATES WEATHER MAPS, $D E C E M B E R, 1878$}

I MPORTANT changes took place this month in the distribution of the earth's atmosphere as compared with what obtained during the previous month, and these were accompanied with at least equally important changes in the geographical distribution of the temperature.

If a line be drawn from Texas to Newfoundland across the Atlantic, the north of France and Germany, thence curving round to-south-eastward through the Black Sea, the Caucasus, India, the East India Islands, and Australia to the south island of New Zealand, it is found to pass through a broad and extended region where atmospheric pressure was throughout considerably below the average of December, and this low pressure was still further deepened at various points along the line. Again, another line passing from Australia through the Philippine Islands, Japan, Mantchooria, Behring's Straits, and Alaska, also marks out an extensive region where pressure was uninterruptedly below the mean.

On the other hand atmospheric pressure was above the average, and generally largely so, over the United States to west of long. $90^{\circ}$, over Greenland, Iceland, Farö, Shetland, and over a large portion of the Old Continent bounded by a line drawn from Lapland round by Lake Balkhash, Canton, Pekin, to at least the upper waters of the Lena. Another area of high pressure extended from Syria, through Egypt and East Africa to the Cape; and part of a third area of high pressure appeared in the north island of New Zealand.

As regards North America, the greatest excess of pressure, 0.196 inch above the average, occurred in the Columbia Valley, from which it gradually fell on proceeding eastward to a defect from the average of 0.146 inch about Lake Champlain and to northward, rising again to near the average on the north of Nova Scotia. To the north-east and north of this region exceedingly high pressures for these regions and the season prevailed, being 0.635 inch above the average in the north-west of Iceland, 0.500 inch in the south of Greenland, and at the three stations in West Greenland, proceeding northwards, $0.445,0.402$, and 0.346 inch.

West Greenland being thus on the west side of the region of high pressure which occupied the northern part of the Atlantic, and on the north-east side of the area of low pressure in the States and Canada, strong southerly winds set in over the country, and the temperature rose at the four Greenland stations proceeding from south to north to $I^{\circ} \cdot 1,8^{\circ} \cdot 8,12^{\circ} \cdot 1$, and $14^{\circ} \cdot 4$, above the averages. As the centre of lowest pressure was in the valley of the St. Lawrence about Montreal, strong northerly and westerly winds predominated to southward and westward, and there consequently the temperature was below the average, the deficiency at Chicago and St. Louis being $9^{\circ} .5$; and winds being easterly and northerly in California, temperature there was also under the average. On the other hand, in the New England States, the greater part of the Dominion of Canada, a considerable portion of British America, and in West Greenland, as already stated, temperature was above the arerage. Pressure was much higher at St. Michael's, Alaska, than it was to south-westward at St. Paul's, Behring Straits, and in connection therewith and with the prevailing winds, the temperature at St. Paul's was $2^{\circ} 9$ below the average, whereas at St. Michael's, where strong southerly winds prevailed, the temperature rose to $12^{\circ} \circ$ o about the normal. Hence whilst the continent of America presented striking contrasts in the distribution of pressure in December, 1878 , it presented still more striking contrasts in the distribution of the temperature. Along Baffin's Bay the excess of the temperature above the normal was $14^{\circ} \cdot 4$, and at Behring Straits $12^{\circ} \circ$, but in the south of Lake Michigan it was $9^{\circ} .4$ below it. In this last case the change of temperature from November to December was probably unprecedented, the mean for November having been $13^{\circ} .7$ above the average (NATURE, vol. xxii. p. 5I6), whilst the December temperature was $9^{\circ} .5$ below it, the difference being $23^{\circ} \cdot 2$ !

Turning now to Europe, it is seen that Iceland lay on the east side of the patch of high pressure which overspread that region, northerly winds consequently prevailed, and with them a lowering of the temperature to $7^{\circ} \cdot 2$ below the average. The contrast this offers to West Greenland is very instructive. In both localities pressure was unusually high, but they occupied different positions, the one on the east and the other on the west of the same area of high pressure, with the inevitable result, of opposite prevailing winds, accompanied in the one case with a temperature $14^{\circ} .4$ above the average, and in the other $7^{\circ} \cdot 2$ below it. Hence as regards the temperature at the surface of the earth, it is not the height of the barometer which rules, but the situation of the locality with respect to areas of high and low pressure; or to put it more popularly, it is the winds which are chiefly concerned in the distribution of the temperature.

In Europe the area of lowest pressure occupied the southern shores of the North Sea, extending thence, though in a less pronounced form, to south-eastward. Hence over the whole of Western Europe winds were north-easterly, northerly, and in the south-west of Europe westerly; thus everywhere, from the North Cape to the north of Italy, temperature was below the normal, in some cases very greatly so, the deficiency being $1^{\circ} .4$ in the south of Norway, and $12^{\circ} \cdot 2$ in the scuth of Scotland. This is lthe lowest monthly mean temperature known to have been recorded in Scotland since thermometric observations began to be made.

On the other hand, to the east of this area of low pressure, winds were southerly, and consequently temperatures were high. In some localities in Russia an excess of about $15^{\circ} \circ$ occurred, and even over a large proportion 